https://doi.org/10.31426/ijamsr.2018.1.9.921

I J A M S R

International Journal of

Advanced Multidisciplinary Scientific Research (IJAMSR) ISSN:2581-4281

\title{
ERROR ANALYSIS IN WRITTEN ENGLISH: A PRAGMATIC STUDY IN THE TERTIARY EDUCATION OF BANGLADESH
}

\author{
Md. Kawser Ahmed \\ Assistant Professor, Department of English, Z. H. Sikder University of Science \& Technology \\ Madhupur, Kartikpur, Bhedergonj, Shariatpur, Bangladesh. \\ Email: kawser.zhsust@gmail.com
}

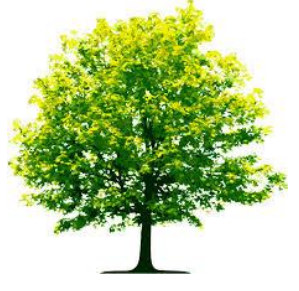

\begin{tabular}{lr}
\hline Keywords: & Accumulation, \\
Assimilate, & Impediments, \\
Lexicon, Tertiary &
\end{tabular}

Lexicon, Tertiary.

\section{Introduction:}

Error analysis in writing English includes a long narrative procedure for both English as second language learners (L2) and English as first language learners (L1).

\begin{abstract}
A B S T RA C T
Attempt to write in English for the tertiary students is a major challenge since they find it as a hard task to make up sentences, consider it as a possible obstacle to assimilate structures between sentences and think of it as an unwanted task to compose a composition maintaining relevant lexicon. This paper will focus on the revelation of an authentic picture of what Bangladeshi university students face impediments in their English as Academic Purposes $(E A P)$, on what impressions they hold about writing in different academic stages and on the practiced pedagogy in writing by academicians in the language classroom. The author of this paper will demonstrate the real picture of errors occurring in writing at Bangladeshi university students in association with data accumulation and data analysis where learners express their genuine interests and available barriers in the arena of writing. In fact, this paper will be a worthy of great interest for those who would like to intend to do research work on writing in the non-native context.
\end{abstract}

Citation: Md. Kawser Ahmed (2018). Error Analysis In Written English: A Pragmatic Study in the Tertiary Education Of Bangladesh. International Journal of Advanced Multidisciplinary Scientific Research (IJAMSR ) ISSN:2581-4281 Vol 1, Issue 9, November, 2018, \#Art.921, pp 76-86 


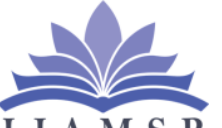

\section{International Journal of Advanced Multidisciplinary Scientific Research (IJAMSR) ISSN:2581-4281}

errors in spite of receiving feedback and guideline from language teachers. In this case, it can be said that some errors are ingrained which a teacher faces more difficulty to absolve his students from these errors and some are unintentional where non-native students find it a great difficulty to overcome this problem. Mistake is a random slip of performance which might occur out of fatigue, excitement and thus these mistakes can be readily self-corrected by themselves (Corder in Larsen:1992).Writing is one of the popularly thought obstacles for the university students of Bangladesh as most of the students have structured assumptions that writing requires to follow grammars, word associations and assembly of sentence structures. All of the determiners regarding writing in English for academic purposes (EAP) pose mixed feelings among the learners of a second language (L2). Many learners think of writing English of some pages would be a great mistake of writing determiners and thus they remain disinterested in practicing writing because it shakes their confidence, leads them to feel vacuum and helps them understand that exact writing is entirely impossible on their part. This picture is very crucial, even in the tertiary education of Bangladesh for medium of answering must be in English. Students might be enrolled in any department or course in university where they are bound to answer to the questions in English which poses a great difficulty upon them. Bangladeshi learners make mistakes subconsciously in writing, though they are quite expert in memorizing written formula and process. The situation becomes more pathetic when students of language courses, literature and applied linguistics do frequent errors in term papers, answer scripts, thesis works and elementary writings like paragraph, job application, invitation letter, memos and report writing.It is generally found that most of the students struggle for writing grammatically flawless sentences and error free writings in different academic sessions, though picture shows us that they cannot get out of the easily solved riddles of making errors subconsciously.In this critical stage of developing writing skills, Harmer (2001: 324) stepped out that students whose native-language orthography is very different from English have difficulty in forming English letters and thus they need to be taught how it should be appropriate. In the data assembly, I will show how students make errors in simple elements of grammar, organization of sentence and choosing of the right word at the right place.

\section{Review of Literature:}

I will focus on what Tribble (1996:37-39) referred to the process of writing is far more complex task as it undergoes through a number of significant stages which include drafting, reviewing, re-drafting and writing and all of the stages are done in a recursive way: we loop backwards and move forwards between these various stages. What Tribble said about the recursive patterns is entirely meaningful and relevant in the context of nonnative writing of English. Teachers, especially language trainers give much more effort on the follow-up of writing processes in which students can have learnability in writing. To set an example, it can be mentioned that almost every public and private university of Bangladesh introduces Foundation Course, Functional English, Advanced Writing, Academic Writing and English for Professional Purposes (EPP). In the courses mentioned above, students are taught to write Englishby formulating tense order, sentence structure, common spellings and development of thought for various purposes. Teachers at the beginning of semesters tend to give more efforts in order that they can make learners 


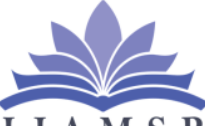

International Journal of Advanced Multidisciplinary Scientific Research (IJAMSR) ISSN:2581-4281

well-efficient to avoid commonly occurred mistakes. Teachers subsequently follow various procedures of writing what Tribble stepped out like making a draft of writing, a review of drafting paragraph or any kind of writing and a final attempt of writing which is called product writing.

Heydariand Begheri (2012) stated,"Writing is a complex process even in the first language. Undoubtedly, it is more complicated to write in a foreign language. Consequently, lots of researchers have intended to identify the common errors EFL students make in writing the second language".

James (1991) made his argument on the basis of distinction between error description and error diagnosis. It is the usual perception that the L2 learners have a subconscious way to make errors which they need to spit out from written composition and subsequently they need to explain the errors like grammatical errors.

Corder (1968: 167) argued, “A learner's errors, then, provide evidence of the system of language that he is using (i.e. has learned) at a particular point in the course (and it must be repeated that he is using some system, although it is not yet the right system)". Learners irrespective of L1 and L2 follow some systems which are universally considered errors, though they are taught systematically briefing well with presentation of structural items, which they are bound to make them occur in regular writing.

Dulay and Burt (1974:1) express their interest regarding errors "You can't learn without goofing". In fact, they say they find an error or "goof" which may occur among the L2 learners as a natural product of the process "for which no blame is implied". The L2 learners undergo different stages of errors because they form the habit of interference of L1 upon L2 learning and learners possess the tendency to cultivate such kind of errors in their everyday writing including academic and professional writing.

Dulay and Burt (1974b) identified three broad dimensions of errors which are as follows:

a) Development (i.e. those errors that are similar to L1 acquisition)

b) Interference (i.e. those errors that reflect the structure of the L1)

c) Unique (i.e. those errors that are neither developmental nor interference)

The categories what Dulay and Burt (1974b) mentioned are availably found among L2 learners because make errors in the same process like acquiring L1, make the representation of grammatical structures of native language and make errors which are not similar to the acquisition of L1 or the influence of grammars of L1.

What Corder (1974), cited in Rod Ellis (1994), expressed in the description of errors is more logical and relevant. He based upon systematicity points out three categories of errors:

a) Presystemati errors occur when the learner is unaware of the existence of a particular rule in the target language. These are random.

b) Systematic errors occur when the learner has discovered a rule, but it is the wrong one.

c) Postsystematic errors occur when the learner knows the correct target language rule, but uses it inconsistently (i.e. makes a mistake). 


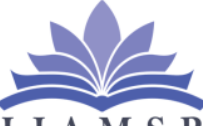

International Journal of Advanced Multidisciplinary Scientific Research (IJAMSR) ISSN:2581-4281

Sipple (1978) advocates the horizon of error analysis as a way of problem solving tasks in which an attempt can be found to discover the rhetorical and linguistic reasons behind the occurrence of error. Error is not an unwelcoming stage in written English and it is mostly dealt with the gradual process of stepping out relevant obstacles in the way of having competence in academic writing at the tertiary level.

Brown (1994:204) discusses the error analysis is the emphasis of learner's errors in their interlanguage system. Error analysis stretches out learner's shortcomings regarding lexical, grammatical and sentence make up of any piece of writing.

The term, interlanguage, coined by Selinker (1972), indicates the systematic knowledge of an L2 which is independent and distinctive of both the learner's L1 and the target language. It can be analyzed that learners need to have well adjusted in the process of learning L2 conniving at the naturalization of L1. It creates a great extent a barricade in the specialization of grammar, vocabulary and other components of writing for the university students.

1. Richards (1970:6) pointed out, “... items produced by the learner, which reflect not the structure of the mother tongue, but generalizations based on partial exposure to the target language". The learner, in this context, attempts to "derive the rules behind the data to which he/she has been exposed, and may develop hypotheses that correspond neither to the mother tongue nor to the target language".

2. In a literature review, I have cited relevant research works which relate to error analysis and all of the citations will work as to identifying core impediments and probable restrictions in writing English at the tertiary education of Bangladesh where learners are required to write in English for many different courses.

\section{Methodology:}

I have conducted a written competition on paragraph writing in a general class by fixing a particular topic among 120 university students of Z.H. Sikder University of Science \& Technology where participants from different departments like Computer Science and Engineering (24), Electrical and Electronic Engineering (21), Chemical Engineering (18), Civil Engineering (12), Law (15), and English (30)took part spontaneously. My empirical study was to detect error from their writing and examine how the non-native learners maintained grammatical structures, selected words and phrases and syntactical patterns in their written paragraph. Though the papers of written task apparently seemed to be disorderly and hassling as I had to check out every single paper with attention and caution for diagnosing where learners got no way out in assembling words into sentences, I went through them very minutely and to the point to make my research more pragmatic and empirical. All of the presentation was made based upon written paragraph by students from varied streams and helped me out to amass a huge pile of errors when I finished checking papers.

\section{Procedure:}

I have conducted a competition on essay writing among 120 students by giving them an identical topic like "Impression about University Life" which required all of the students to write sentences outlining the topic with elaborate discussion. Examinees were given the question 
https://doi.org/10.31426/ijamsr.2018.1.9.921

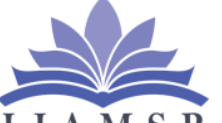

\section{International Journal of Advanced Multidisciplinary Scientific Research (IJAMSR) ISSN:2581-4281}

paper along with separate sheets and they were asked to start writing when I told them to do so. Students were given 60 minutes and they were strictly instructed to write within 400 words, though the number of words varied upon the basis of students' writing style, and told them to stop writing when the allocated time being up. I focused initially on sampling of errors from the submitted papers, identifying the errors like spellings, grammars and organization of sentences they made on individual papers and describing the errors based upon sampling and identifying them with adequate and direct presentation of errors from students' papers. Irrespective of any specific department, I penned through the papers to make an actual observation why Bangladeshi students are vulnerable to more errors and how they can come out of the barriers of making errors in written English at a university education. To give a good explanation of error detection, I need to say that I went through every paragraph written on sheets. Firstly, I counted how many spelling mistakes they made, I encircled on which major grammatical points they made errors and I spotted out the misappropriation of words. All of the checking procedures were finished in a traditional answering script checking manner, though this method of checking was time consuming and monotonous.

\section{Results of the Study:}

Following is the table where I have presented the direct citation of sentences full of errors, step out of the errors and the explanation of the errors which will make researchers well understand an authentic picture of erroneous English taught in different fundamental courses at university of Bangladesh. However, this methodological study does not actually depict the true scenario of poor written English by Bangladeshi learners.
Table 1: Presentation of Errors Numerically

\begin{tabular}{|c|c|c|c|c|}
\hline $\begin{array}{l}\text { Items } \\
\text { Teste } \\
\text { d }\end{array}$ & $\begin{array}{l}\text { Form of } \\
\text { Error }\end{array}$ & $\begin{array}{l}\text { Numbe } \\
\mathbf{r \quad \text { of }} \\
\text { Errors }\end{array}$ & $\begin{array}{l}\text { Percentag } \\
\text { e }\end{array}$ & $\begin{array}{l}\text { Mea } \\
\text { n }\end{array}$ \\
\hline 1 & Spellings & 1274 & 19.83 & 10.61 \\
\hline 2 & $\begin{array}{l}\text { Conjugation } \\
\text { of Tense }\end{array}$ & 820 & 12.76 & 6.83 \\
\hline 3 & $\begin{array}{l}\text { Singular and } \\
\text { Plural }\end{array}$ & 624 & 9.71 & 5.2 \\
\hline 4 & $\begin{array}{l}\text { Omission of } \\
\text { "Be" Verb }\end{array}$ & 502 & 7.81 & 4.18 \\
\hline 5 & $\begin{array}{l}\text { Subject-Verb } \\
\text { Agreement }\end{array}$ & 428 & s6.66 & 3.57 \\
\hline 6 & $\begin{array}{ll}\text { Diction } & \text { or } \\
\text { Selection } & \text { of } \\
\text { Words } & \end{array}$ & 390 & 6.07 & 3.25 \\
\hline 7 & Preposition & 378 & 5.88 & 3.15 \\
\hline 8 & Article & 370 & 5.76 & 3.08 \\
\hline 9 & Capitalization & 326 & 5.07 & 2.72 \\
\hline 10 & Missing Word & 292 & 4.55 & 2.43 \\
\hline 11 & Punctuation & 266 & 4.14 & 2.22 \\
\hline 12 & Redundancy & 240 & 3.73 & 2 \\
\hline 13 & Parallelism & 188 & 2.93 & 1.57 \\
\hline 14 & $\begin{array}{l}\text { Wrong/Misuse } \\
\text { d Word }\end{array}$ & 180 & 2.80 & 1.5 \\
\hline \multirow[t]{2}{*}{15} & Word Order & 148 & 2.30 & 1.23 \\
\hline & Total & 6426 & 100 & \\
\hline
\end{tabular}

Students showed a strong tendency of making errors in most frequent determiners like Spellings, Conjugation of Tense, Singular and Plural, Omission of "Be" Verb, Subject-Verb Agreement and other forms of grammars. The sampling referred to the instant performance and presented an authentic presentation of how many errors 


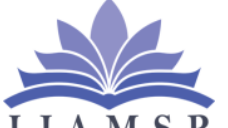

\section{International Journal of Advanced Multidisciplinary Scientific Research (IJAMSR) ISSN:2581-4281}

were committed by the individual student in a particular type of error. Number of errors, percentage and mean indicate the authentic picture of making errors by the university students of Bangladesh.

What we see from Table 1 is that students made more errors in Spellings (10.61) and Conjugation of Tense (6.83) was the next most mistakenly arenas of errors by Bangladeshi learners. Students made errors in Singular and Plural (5.2) where they showed the vulnerability in making the difference between singular and plural items. Omission of "Be" Verb (4.18) and Subject-Verb Agreement (3.57) was the common grammatical erroneous items committed by students. In addition, students showed their weaknesses in Diction or Selection of Words (3.25), Preposition (3.15), Article (3.08), Capitalization (2.72), Missing Word (2.43) and Punctuation (2.22). The mean of errors done by students was the manifestation of error propensity in writing English even among university students of Bangladeshi.

\section{Formula Used for Percentage and Mean:}

In case of finding out the percentage, I have used the formula mentioned below:

Percentage $=$ Number of ErrorsX100

\section{Total Errors}

In case of finding out mean, I have used the formula mentioned below:

Mean $=$ Number of Errors

Total Participants

\section{Table 2: Frequently Done Errors}

Table 2 explains the number of error types done by students in a single sitting test. The table includes types of errors, identification of errors and explanation of errors with feedback. This section of paper will demonstrate that Bangladeshi students make errors and presentation of possible explanations.

\begin{tabular}{|c|c|c|}
\hline Error Type & $\begin{array}{l}\text { Identification of } \\
\text { Errors }\end{array}$ & Correct Sentences \\
\hline $\begin{array}{l}\text { Spellings } \\
\text { (Students made } \\
\text { frequent errors in } \\
\text { spelling of } \\
\text { common words) }\end{array}$ & $\begin{array}{l}\text { 1. We can learn } \\
\text { some bassic rules } \\
\text { from university. } \\
\text { 2. University has } \\
\text { a commiteefor the } \\
\text { welfare of } \\
\text { students. } \\
\text { 3. Accomodation } \\
\text { is one of the } \\
\text { major problems in } \\
\text { university. } \\
\text { 4. Iregular classes } \\
\text { happen in } \\
\text { university } \\
\text { context. }\end{array}$ & $\begin{array}{l}\text { 1. We can learn } \\
\text { some basic rules } \\
\text { from university. } \\
\text { 2. University has a } \\
\text { committee for the } \\
\text { welfare of } \\
\text { students. } \\
\text { 3. Accommodation } \\
\text { is one of the major } \\
\text { problems in } \\
\text { university. } \\
\text { 4. Irregular classes } \\
\text { happen in } \\
\text { university context. }\end{array}$ \\
\hline $\begin{array}{l}\text { Conjugation of } \\
\text { Tense } \\
\text { (Students show a } \\
\text { great tendency in } \\
\text { making errors in } \\
\text { right use of tenses) }\end{array}$ & 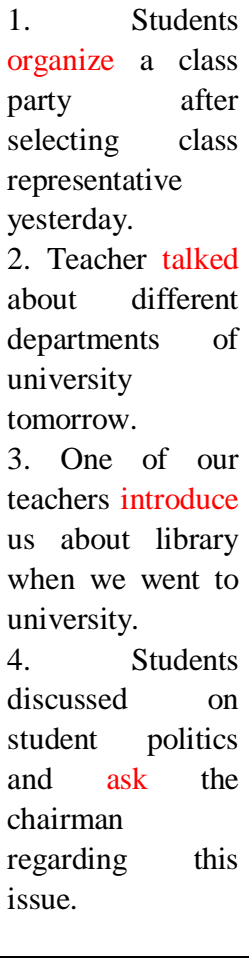 & 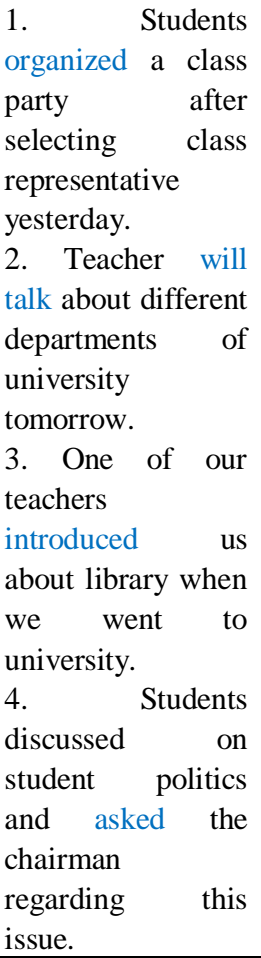 \\
\hline
\end{tabular}




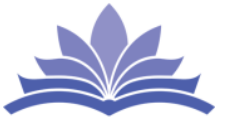

\section{International Journal of}

\section{Advanced Multidisciplinary Scientific Research (IJAMSR) ISSN:2581-4281}

\section{Singular and Plural (Test givers were unable to make difference between spoken and written English because they were not concerned about singular or plural expressions.)}

1. I have a good
number of
impression and
experienceabout
this university.
2. I have some
friend and
classmate who
help me in class
notes.

3. Teacher

teaches us many

topic and

discusses many concept in lecture.

4. All of the student need to take photocopy from class representative and are friendly to us.

Omission of "Be" 1.

Verb

(Students very often forget to write "Be" verbs like am, is, are, was, have or has in structuring sentences and they remain subconscious when they make errors in this regard.) English because it all of the officer
Students/playing in the university playground when they free.

2. Teachers $\Lambda$ well care of the spoken essential for students in all departments.

3. University authority $/$ helpful for the betterment of students and they /cooperative in any kind of necessity.

4. I having a good impression about my university and thinking about its progress. number

impressions and experiences about this university.

2. I have some friends and classmates who help me in class notes.

3. Teacher teaches us many topics and discusses many concepts in lecture. 4. All of the students need to take photocopy from class representative and all of the officers are friendly to us.

1. Students are playing in the university playground when they are free.

2. Teachersarewell care of the spoken English because itis essential for students in all departments.

3. University authority is helpful for the betterment of students and they are cooperative in any kind of necessity.

4. I have a good impression about my university and think about its progress.

\begin{tabular}{|l|l|l|}
\hline $\begin{array}{l}\text { Subject-Verb } \\
\text { Agreement }\end{array}$ & $\begin{array}{l}\text { 1. A large number } \\
\text { of } r \text { students }\end{array}$ & \multicolumn{2}{l|}{ of large number } \\
of is pity to say & participates in students & participate in \\
\hline
\end{tabular}

\begin{tabular}{|c|c|c|}
\hline $\begin{array}{l}\text { that students are } \\
\text { not concerned } \\
\text { about the } \\
\text { agreement of } \\
\text { subjects with } \\
\text { verbs. They are not } \\
\text { competent enough } \\
\text { in applying the } \\
\text { rules of subject } \\
\text { verb agreement in } \\
\text { written task.) }\end{array}$ & 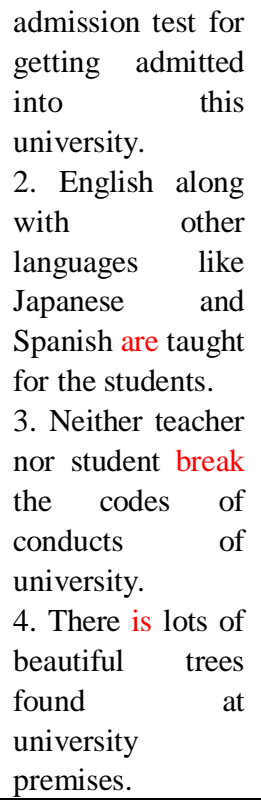 & 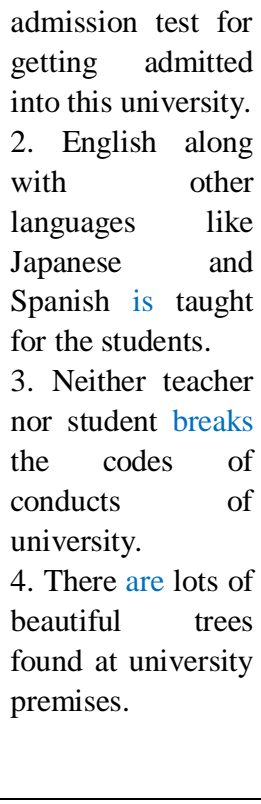 \\
\hline $\begin{array}{l}\text { Diction or } \\
\text { Selection of Words } \\
\text { (Second language } \\
\text { learners of English } \\
\text { wrongly choose } \\
\text { words and they use } \\
\text { words } \\
\text { inappropriate } \\
\text { places.) }\end{array}$ & $\begin{array}{l}\text { 1. Classrooms are } \\
\text { organized with } \\
\text { modern amenities } \\
\text { and teachers run } \\
\text { the class with } \\
\text { overhead } \\
\text { projector. } \\
2 . \text { Students are } \\
\text { regulated to } \\
\text { follow the set } \\
\text { rules of university } \\
\text { and they are } \\
\text { obliged to check } \\
\text { notice every day. } \\
\text { 3. All of the } \\
\text { students attended } \\
\text { the introductory } \\
\text { program and they } \\
\text { were exhilarated } \\
\text { much in the } \\
\text { beginning day. } \\
4 . \\
\text { function Teachers some } \\
\text { basic English } \\
\text { courses and they } \\
\text { estimate these } \\
\text { courses will bring } \\
\text { about benefits for } \\
\text { the students. }\end{array}$ & $\begin{array}{l}\text { 1. Classrooms are } \\
\text { decorated with } \\
\text { modern amenities } \\
\text { and teachers } \\
\text { conduct the class } \\
\text { with overhead } \\
\text { projector. } \\
2 \text { Students are } \\
\text { bound to follow } \\
\text { the set rules of } \\
\text { university and they } \\
\text { are instructed to } \\
\text { check notice every } \\
\text { day. All of the } \\
3 . \quad \text { attended } \\
\text { students orientation } \\
\text { the impressed } \\
\text { program and they } \\
\text { were in the } \\
\text { much in } \\
\text { beginning day. } \\
4 . \quad \text { Teachers } \\
\text { introduce some } \\
\text { basic English } \\
\text { courses and they } \\
\text { think these courses } \\
\text { will bring about } \\
\text { benefits for the } \\
\text { students. }\end{array}$ \\
\hline $\begin{array}{l}\text { Preposition } \\
\text { (ESL learners find } \\
\text { preposition as one } \\
\text { of the difficult } \\
\text { grammatical }\end{array}$ & $\begin{array}{l}\text { 1. The orientation } \\
\text { program was held } \\
\text { in the university } \\
\text { premises and all } \\
\text { of the flower }\end{array}$ & $\begin{array}{l}\text { 1. The orientation } \\
\text { program was held } \\
\text { at the university } \\
\text { premises and all of } \\
\text { the flower }\end{array}$ \\
\hline
\end{tabular}




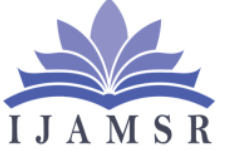

\section{International Journal of Advanced Multidisciplinary Scientific Research (IJAMSR) ISSN:2581-4281}

\begin{tabular}{|l|l|l|}
\hline structures because & bouquets were set & bouquets were set
\end{tabular} it has variation of at the table. use at different positions)

\section{Students abide} to the university

on the table.

2. Students abide

by the university

\section{Article}

(Article is another commonly used grammatical item where students make errors in their right use at right place. Students wrongly place article without having much knowledge on it.) rules and regulations and they should not be indifferent at any of the set rules.

3. Cafeteria is established beyond the university campus and students are required to walk by foot to take foods.

4. Students play across university playground and they enjoy their leisure time at the afternoon.

1. Students have 1. Students have a
an union for their basic demands. University has a two storied buildings for academic and administrative works. 2. A Vice Chancellor is the head of academic affairs and a Registrar is the head managerial affairs.

3. Students are a members of different clubs and cultural committee and they play a outstanding role in their career.

4. A location of this university is comfortable for students and they do their lunch in a rules and

regulations and

they should not be indifferent to any of the set rules.

3. Cafeteria is establishedoutside

the university

campus and students are required to walk on foot to take foods.

4. Students play at the university playground and they enjoy their leisure time in the afternoon.

\section{Students have a} union for their basic demands. University has the two storied buildings for academic and administrative works.

2. The Vice Chancellor is the head of academic affairs and the Registrar is the head administrative affairs.

3. Students are the members of different clubs and cultural committee and they play an outstanding role in their career.

4. The location of this university is comfortable for students and they do their lunch in the university

\begin{tabular}{|c|c|c|}
\hline & $\begin{array}{l}\text { university } \\
\text { canteen. }\end{array}$ & \\
\hline $\begin{array}{l}\text { Capitalization } \\
\text { (Capitalization is } \\
\text { one of the } \\
\text { grammatical } \\
\text { structures where } \\
\text { students fail to } \\
\text { capitalize words } \\
\text { especially naming } \\
\text { words, places, } \\
\text { streets, shops and } \\
\text { some } \\
\text { terminologies.) }\end{array}$ & $\begin{array}{l}\text { 1. At the } \\
\text { orientation } \\
\text { program, I made } \\
\text { some of my } \\
\text { friends namely } \\
\text { Firozsheikh and } \\
\text { Jahir khan who } \\
\text { were very friendly } \\
\text { and cooperative } \\
\text { with me. } \\
\text { 2. I visited many } \\
\text { different places of } \\
\text { the university like } \\
\text { the registrar } \\
\text { building and the } \\
\text { admission office } \\
\text { when I had some } \\
\text { official works. } \\
\text { 3. Sometimes I } \\
\text { had to go to the } \\
\text { dean office } \\
\text { regarding my } \\
\text { admission related } \\
\text { activities and to } \\
\text { meet the proctor } \\
\text { for the purpose of } \\
\text { getting the } \\
\text { booklet } \\
\text { ofproctor's } \\
\text { guidelines. } \\
4 . \text { The chairman } \\
\text { of my department } \\
\text { was very cordial } \\
\text { to us and he took } \\
\text { one of our courses } \\
\text { like basic } \\
\text { grammar. }\end{array}$ & $\begin{array}{l}\text { 1. At the } \\
\text { orientation } \\
\text { program, I made } \\
\text { some of my friends } \\
\text { namely } \\
\text { FirozSheikh and } \\
\text { Jahir Khan who } \\
\text { were very friendly } \\
\text { and cooperative } \\
\text { with me. } \\
\text { 2. I visited many } \\
\text { different places of } \\
\text { the university like } \\
\text { the } \\
\text { Registrarbuilding } \\
\text { and the Admission } \\
\text { office when I had } \\
\text { some official } \\
\text { works. } \\
\text { 3. Sometimes I had } \\
\text { to go to the Dean } \\
\text { office regarding } \\
\text { my admission } \\
\text { related activities } \\
\text { and to meet the } \\
\text { Proctorfor the } \\
\text { purpose of getting } \\
\text { the booklet } \\
\text { ofProctor's } \\
\text { guidelines. } \\
\text { 4. The Chairman } \\
\text { of my department } \\
\text { was very cordial to } \\
\text { us and he took one } \\
\text { of our courses like } \\
\text { Basic Grammar. }\end{array}$ \\
\hline $\begin{array}{l}\text { Missing Word } \\
\text { (It is very common } \\
\text { to find that } \\
\text { students have a } \\
\text { great tendency to } \\
\text { miss some words } \\
\text { or phrases when } \\
\text { they write their } \\
\text { answer on scripts.) }\end{array}$ & $\begin{array}{l}\text { 1. In the }(\ldots . . .) \text {, } \\
\text { many students } \\
\text { found university } \\
\text { teaching and } \\
\text { learning difficult } \\
\text { to understand and } \\
\text { to pass the }(. . . \ldots) \text {. } \\
2 . \\
\text { environment of } \\
(\ldots \ldots .) \text { attracted } \\
\text { me much and I } \\
\text { was very }(. . . . .) \\
\text { to study in this } \\
\text { university. } \\
3 . \text { My senior }\end{array}$ & $\begin{array}{l}\text { 1. In the } \\
\text { beginning, many } \\
\text { students found } \\
\text { university teaching } \\
\text { and learning } \\
\text { difficult to } \\
\text { understand and to } \\
\text { pass theexam. } \\
2 . \\
\text { environment } \\
\text { ofcampus attracted } \\
\text { me much and I } \\
\text { was veryglad to } \\
\text { study in this } \\
\text { university. }\end{array}$ \\
\hline
\end{tabular}


https://doi.org/10.31426/ijamsr.2018.1.9.921

\section{International Journal of Advanced Multidisciplinary Scientific Research (IJAMSR) ISSN:2581-4281}

\begin{tabular}{|c|c|c|}
\hline & $\begin{array}{l}\text { brothers and } \\
(\ldots . . . .) \text { helped me } \\
\text { much when I } \\
\text { faced any }(\ldots . . .) \\
\text { and suggested me } \\
\text { to prepare notes } \\
\text { myself. } \\
\text { 4. Very }(. . . . .), \text { I } \\
\text { prepared my } \\
\text { study } \\
\text { participating in } \\
\text { group study and } \\
\text { attended } \\
\text { tutorials } \\
\text { in }(. . . . .) .\end{array}$ & $\begin{array}{l}\text { 3. My senior } \\
\text { brothers andsisters } \\
\text { helped me much } \\
\text { when I faced } \\
\text { anyproblem and } \\
\text { suggested me to } \\
\text { prepare notes } \\
\text { myself. } \\
\text { 4. Veryoften, I } \\
\text { prepared my study } \\
\text { participating in } \\
\text { group study and } \\
\text { attended the } \\
\text { tutorials intime. }\end{array}$ \\
\hline $\begin{array}{l}\text { Punctuation } \\
\text { (Students } \\
\text { more face } \\
\text { problems } \\
\text { placing } \\
\text { punctuation marks } \\
\text { like comma, } \\
\text { semicolon, hyphen, } \\
\text { full stop, inverted } \\
\text { comma, question } \\
\text { mark and note of } \\
\text { exclamation.) }\end{array}$ & $\begin{array}{l}\text { 1. What was the } \\
\text { exact date of my } \\
\text { first class at this } \\
\text { university I could } \\
\text { not recall. } \\
\text { (Question mark) } \\
\text { 2. I saw many } \\
\text { new faces at the } \\
\text { first day in my } \\
\text { university My } \\
\text { new friends gave } \\
\text { me much pleasure } \\
\text { when I came } \\
\text { across them.(Full } \\
\text { stop) } \\
\text { 3. Our class } \\
\text { teacher told, } \\
\text { Industry is the } \\
\text { key to } \\
\text { success.(Inverted } \\
\text { comma) } \\
\text { 4. I visited the } \\
\text { central library the } \\
\text { central mosque } \\
\text { and played some } \\
\text { indoor games. } \\
\text { (Comma) }\end{array}$ & $\begin{array}{l}\text { 1. What was the } \\
\text { exact date of my } \\
\text { first class at this } \\
\text { university I could } \\
\text { not recall? } \\
\text { 2. I saw many new } \\
\text { faces at the first } \\
\text { day in my } \\
\text { university. My } \\
\text { new friends gave } \\
\text { me much pleasure } \\
\text { when I came } \\
\text { across them. } \\
\text { 3. Our class } \\
\text { teacher told, } \\
\text { "Industry is the } \\
\text { key to success". } \\
\text { 4. I visited the } \\
\text { central library, the } \\
\text { central mosque } \\
\text { and played some } \\
\text { indoor games. }\end{array}$ \\
\hline $\begin{array}{l}\text { Redundancy } \\
\text { (Students have } \\
\text { built in habit to } \\
\text { rephrase or repeat } \\
\text { the same words or } \\
\text { rewrite on their } \\
\text { scripts, though they } \\
\text { do it } \\
\text { subconsciously and } \\
\text { without knowing } \\
\text { the exact } \\
\text { application of the }\end{array}$ & $\begin{array}{l}\text { 1. I checked the } \\
\text { notice board } \\
\text { repeatedly again } \\
\text { and again and } \\
\text { rewrote all notices } \\
\text { on papermore } \\
\text { than once. } \\
\text { 2. Students were } \\
\text { instructed to carry } \\
\text { materials } \\
\text { documents with } \\
\text { them and they }\end{array}$ & $\begin{array}{l}\text { 1. I checked the } \\
\text { notice board } \\
\text { repeatedly and } \\
\text { rewrote all notice } \\
\text { on paper. } \\
\text { 2. Students were } \\
\text { instructed to carry } \\
\text { materials with } \\
\text { them and they } \\
\text { were obliged to } \\
\text { obey what their }\end{array}$ \\
\hline
\end{tabular}

\begin{tabular}{|c|c|c|}
\hline $\begin{array}{l}\text { rules } \\
\text { redundancy.) }\end{array}$ & $\begin{array}{l}\text { were obliged } \\
\text { forced to obey } \\
\text { what their } \\
\text { teachers told. } \\
\text { 3. In grammar } \\
\text { classes, teacher } \\
\text { taught us how to } \\
\text { complete drills } \\
\text { and exercisesand } \\
\text { solve them } \\
\text { frequently } \\
\text { regularly. } \\
\text { 4. Besides my } \\
\text { department, I } \\
\text { found gathering } \\
\text { of students from } \\
\text { other departments } \\
\text { crowded in } \\
\text { general class. }\end{array}$ & $\begin{array}{l}\text { teachers told. } \\
\text { 3. In grammar } \\
\text { classes, teacher } \\
\text { taught us how to } \\
\text { complete drills and } \\
\text { solve them } \\
\text { frequently. } \\
4 \text { Besides my } \\
\text { department, } \\
\text { found gathering of } \\
\text { students from } \\
\text { other departments } \\
\text { in general class. }\end{array}$ \\
\hline $\begin{array}{l}\text { Parallelism } \\
\text { (It can be seen that } \\
\text { students lose } \\
\text { rhythm or parallel } \\
\text { structures in their } \\
\text { writing and they } \\
\text { almost forget to } \\
\text { maintain order or } \\
\text { sequence what is } \\
\text { strongly needed in } \\
\text { written English.) }\end{array}$ & $\begin{array}{l}\text { 1. My first } \\
\text { impression about } \\
\text { this university is } \\
\text { that the university } \\
\text { is well-structured } \\
\text { in appearance, } \\
\text { well-organized in } \\
\text { academicactivity } \\
\text { and furnish in } \\
\text { outlook. } \\
\text { 2. Teaching staffs } \\
\text { of this university } \\
\text { are dedicated, } \\
\text { passion and } \\
\text { committed to their } \\
\text { job responsibility. } \\
\text { 3. This university } \\
\text { is free from } \\
\text { politics, drug } \\
\text { abuse and } \\
\text { harassed in any } \\
\text { form. } \\
\text { 4. Teachers take } \\
\text { the class, take } \\
\text { attendance and } \\
\text { doing work } \\
\text { sincerely. }\end{array}$ & $\begin{array}{l}\text { 1. My first } \\
\text { impression about } \\
\text { this university is } \\
\text { that the university } \\
\text { is well-structured } \\
\text { in appearance, } \\
\text { well-organized in } \\
\text { academic activity } \\
\text { and well-furnished } \\
\text { in outlook. } \\
\text { 2. Teaching staffs } \\
\text { of this university } \\
\text { are dedicated, } \\
\text { passionate and } \\
\text { committed to their } \\
\text { job responsibility. } \\
\text { 3. This university } \\
\text { is free from } \\
\text { politics, drug } \\
\text { abuse and } \\
\text { harassment in any } \\
\text { form. } \\
\text { 4. Teachers take } \\
\text { the class, take } \\
\text { attendance and do } \\
\text { work sincerely. }\end{array}$ \\
\hline $\begin{array}{l}\text { Wrong/Misused } \\
\text { Word } \\
\text { (Inappropriateness } \\
\text { of application of } \\
\text { word creates } \\
\text { confusion in } \\
\text { understanding what }\end{array}$ & $\begin{array}{l}\text { 1. Most of the } \\
\text { students are } \\
\text { interested on } \\
\text { using internet and } \\
\text { they are fond in } \\
\text { playing cards and } \\
\text { table tennis at }\end{array}$ & $\begin{array}{l}\text { 1. Most of the } \\
\text { students are } \\
\text { interested in using } \\
\text { internet and they } \\
\text { are fond of playing } \\
\text { cards and table } \\
\text { tennis at leisure }\end{array}$ \\
\hline
\end{tabular}




\begin{tabular}{|c|c|c|}
\hline $\begin{array}{l}\text { is commonly found } \\
\text { in students' } \\
\text { writings because } \\
\text { they use words } \\
\text { without justifying } \\
\text { relevancy and } \\
\text { appropriateness.) }\end{array}$ & $\begin{array}{l}\text { leisure time. } \\
\text { 2. Topics are } \\
\text { conceptauble to } \\
\text { students when } \\
\text { they go through } \\
\text { texts. } \\
\text { 3. Students are } \\
\text { sincerable } \\
\text { regarding } \\
\text { following rules } \\
\text { and regulations of } \\
\text { university. } \\
\text { 4. The authority is } \\
\text { carefulation about } \\
\text { the development } \\
\text { of university. }\end{array}$ & $\begin{array}{l}\text { time. } \\
\text { 2. Topics are } \\
\text { conceptual to } \\
\text { students when they } \\
\text { go through texts. } \\
\text { 3. Students are } \\
\text { sincere regarding } \\
\text { following rules } \\
\text { and regulations of } \\
\text { university. } \\
\text { 4. The authority is } \\
\text { carefulabout the } \\
\text { development of } \\
\text { university. }\end{array}$ \\
\hline $\begin{array}{l}\text { Word Order } \\
\text { (Students make a } \\
\text { disorder in writing } \\
\text { paragraph or any } \\
\text { kind } \\
\text { composition } \\
\text { because they are } \\
\text { not expert in } \\
\text { implementing } \\
\text { sequence } \\
\text { words.) }\end{array}$ & $\begin{array}{l}\text { 1. Teachers think } \\
\text { very much about } \\
\text { the progress of } \\
\text { students. } \\
\text { 2. Students can } \\
\text { books easily take } \\
\text { from university } \\
\text { library. } \\
\text { 3. University } \\
\text { environment } \\
\text { comfortable and } \\
\text { enjoyable is to } \\
\text { other students. } \\
4 \text { Fortunately, } \\
\text { found I a number } \\
\text { of friends who } \\
\text { became close to } \\
\text { me. }\end{array}$ & $\begin{array}{l}\text { 1. Teachers very } \\
\text { much think about } \\
\text { the progress of } \\
\text { students. } \\
2 . \text { Students can } \\
\text { take books easily } \\
\text { from university } \\
\text { library. } \\
\text { 3. University } \\
\text { environment is } \\
\text { comfortable and } \\
\text { enjoyable to other } \\
\text { students. } \\
4 . \text { Fortunately, I } \\
\text { found a number of } \\
\text { friends who } \\
\text { became close to } \\
\text { me. }\end{array}$ \\
\hline
\end{tabular}

\section{Limitations of the Study:}

As I concentrated on the detection of errors and analyses of errors in the written English of Bangladeshi university students, I conducted a written composition test by which I would be able to identify a number determiners like Spellings, Conjugation of Tense and Singular and Plural in students' written works. I found 120 students from different departments sitting for single test and they have written what they had in their minds based upon the topic given. The participation of huge number of students in writing test was appreciatory but checking answer scripts were very strenuous and troublesome. It created a little confusion in smooth methodological procedures of the study. The number of students, 120 in number, appearing for writing composition did not give out the exact result that all of the students were weak at guided or semi-guided writing. The study was conducted in a particular university of certain number of students. Sampling is the provocation of actual result, but it is not accurate and authentic always. Writing is one of the four skills where native and non-native are equal in writing poor grammatical rules and same in making errors because writing requires the follow up grammatical structures, appropriate sentence organization and maintenance of sequence. In addition, students are not equally proficient in applying all of the determiners of grammar and they very often fail to have mastery on all of the items. Modern equipment and other logistical supports regarding checking and marking students' papers might bring about more authenticity and appropriateness in the study of measurement.

\section{Conclusion:}

The paper concentrates on the written performance of the students, especially of the tertiary students who are studying in different popular and life oriented departments. Since they are required to write in English, prepare their notes in English, prepare presentation and conference papers in English, it can be assumed that they need to possess a strong command over written English. In addition, students, especially students of language and literature need to be error free in writing English because theory and practice of English language is reflected in these specified students. Drafting an invitation letter, 
https://doi.org/10.31426/ijamsr.2018.1.9.921

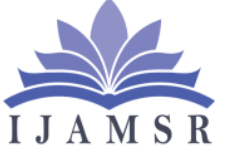

\section{International Journal of}

\section{Advanced Multidisciplinary Scientific Research (IJAMSR) ISSN:2581-4281}

writing a formal letter, circulating office memorandum and composing business letters require error free, precise and to the point writing which will express of interest in a clear way. This paper will address the possible obstacles in the way of analyzing error through a numerical study along with the summarization of a numerical study resulting in L1 learners face more problems in associating words for understandable and meaningful sentences. This paper will spit out probable obstacles in the way of effective written English and be a good source of information regarding identifying errors for Bangladeshi students.

\section{References}

1) Brown, D. B. (1994). Principles of language learning and teaching. Third Edition. New Jersey:Prentice Hall.

2) Corder, S. P. (1967). The significance of learners' errors. International Review of Applied Linguistics, 5(4), 161-169.

3) Dulay, H.C. and Burt, M.K.(1972). Goofing: An indicator of children's second language learning strategies. Language Learning 22:235-252.

4) Ellis, R. (1994). The Study of Second Language Acquisition. New York: Oxford University Press.

5) Ellis, R. (1996). Second language acquisition research and language teaching. Oxford: Oxford University Press.

6) Harmer, J. (2001). The Practice of English Language Teaching. (Third Edition). Essex: Longman Group UK Ltd.

7) Heydari,P, andBegheri,M.S.(2012).Error Analysis: Sources of L2 Learners" Errors. Theory andPractice in Language Studies, 2, 1583-1589.
8) James, C. (1988). Errors in Language Learning Use: Exploring Error Analysis. Harlow, Essex: Addison Wesley Longman Limited.

9) Selinker, L. (1972). Interlanguage. International Review of Applied Linguistics, 10 , 209-231.

10) Sipple, Jo-Ann M. (1978). Error Analysis: How to Translate It into Positive Teaching.

11) (ERIC Document Reproduction Service No. ED 161044) Retrieved May 29, 2009,from ERIC database. (ERIC Document Reproduction Service No. ED 161044) Retrieved May 29, 2009, from ERIC database.

12) Tribble, C. (1996). Writing. Oxford: Oxford University Press. 